\title{
RAINFALL IMPLICATIONS FOR FOOD PRODUCTION IN INDIA: WHEN AND WHERE
}

\author{
Nilabja Ghosh ${ }^{1}$, M. Rajeshwor ${ }^{1}$, Amritanshi Preeti $^{2}$ \\ ${ }^{1}$ FASAL, Institute of Economic Growth, Delhi University Enclave, Delhi - (nila, rajeshwor)@iegindia.org \\ ${ }^{2}$ Student of Hans Raj College Delhi University, Delhi - amritanshipreeti3@gmail.com
}

Commission III, WG III/10

KEY WORDS: Upstream-downstream linkage, Reservoir, Irrigation, Climate change, Spatial effect of rainfall, Water management

\begin{abstract}
:
Early outlook on food production is important for policy making and can be formed on the basis of the recorded rainfall. Simplistically, a good monsoon produces a bumper harvest and scanty rainfall causes crop failure. Econometric modelling of past data shows that the reality is much more complex. Food production in a state is sensitive to rainfall in the state as well as other states depending on geography. Rainfall distribution in the growing season and pre-sowing months can matter significantly. Moreover, the rainfall effect can be favorable as well as adverse. In the sample period, sowing and growing season rainfall in the state had little favorable effect on area and yield in Punjab and its effect on Rice yield was even harmful in Punjab and West Bengal. Rainfall in Uttar Pradesh and Madhya Pradesh however had beneficial effects on the respective state's and on each's other production. Rainfall in the Himalayas is a powerful impact on food production resulting from river dynamics and water management but the dominance of adverse effect over beneficial ones is a sign of poorly managed upstream downstream linkages. Because production is sensitive also to economic variables, the government, which can modulate subsidies and support prices, also has control over food production. Improving efficiency of water distribution with an integrated geographical perspective can also be a potent public instrument for production planning.
\end{abstract}

\section{INTRODUCTION}

Monitoring the outlook of agriculture has become a serious task for ensuring economic and nutritional well-being of the global populace. While conventional methods of measuring food production need strengthening with improved communication technologies, non-conventional measurement systems, of which remote sensing (RS) is the most outstanding, are also emerging. In India, the use of RS for estimating food production is institutionalized in a government sponsored project called FASAL $^{1}$ which is collaborative and comprehensive in bringing under its coverage other methods beyond space application.

FASAL attempts to generate multiple in-season forecasts to create continual outlook on food production and enable timely policy making to avoid crisis in agriculture and the nation's food economy. Econometrics, based on models and past data is one of its components which is useful for its capability to make forecasts at various stages starting from sowing, when fieldbased estimates are largely subjective and RS has too little spectral information to process, up to the harvest stages when more method based, robust and scientific estimates become available. In essence, the econometric model identifies the driving factors that determine the acreage and yield rate per unit area of any crop in any spatial unit and the impact of the same factors so far as available official data would enable. It then goes forward to make the forecast using the estimated relation and the outlook on the driving variables as received from other scientific sources or projected as scenarios for simulation.

\footnotetext{
*Corresponding Author: Nilabja Ghosh

${ }^{1}$ Forecasting Agricultural Output using Space, Agro-meteorology and Land-based Observations
}

Together, the acreage and yield forecasts help to project the production outlook.

Early production information has always been of interest to policy makers, traders, revenue collectors, credit and insurance agencies, input manufacturers, speculators and the market at large. Rainfall is a phenomenon that is observable to the data agencies and also to the common people far ahead of the time when production reaches the market and imprints the prices. It is therefore a convenient leading indicator ${ }^{2}$ of farm production which is unknown at the growing stages. For centuries and in most of the earlier protocols, rainfall (excess, normal or deficit) was taken as a yardstick to mark the departure of production from its normal secular path. On the other hand, a model can help to explicitly capture the effect of rainfall, controlling for other possible influences, in order to make more objective projections of the production than perceptions can.

Poor monsoon is associated with crop failure and a good monsoon with a bumper harvest. However, while this empirical association as a general statement is intuitively beyond question, the true relation is far more complex. Firstly, there are other variables the significance of which is becoming increasingly recognized. Temperature is one such determinant of crop yield that the literature on climate change emphasizes. Secondly, with increasing commercialization of the rural sector, markets are becoming important for the choice of crops for planting and for allocating inputs. Moreover, the government manipulates incentives by revising the minimum support prices (MSP). In other words, economic variables namely the prices of

\footnotetext{
${ }^{2}$ Leading indicators help market observers and policymakers predict significant changes in the economy but they are not always accurate.
} 
crops and inputs and the MSPs can be decisive for production, allowing for substitution among crops by farmers. Thirdly, the average annual rainfall in the country as a representative figure is highly limited in meaningfulness. India is a large and climatically diverse country and regional variations of rainfall are considerable. The effect of rainfall on various crops will depend on the distribution of the crops areas across the country, their differential needs and the regional rainfall patterns.

Fourth, rainfall is not the only source of water for agriculture. Irrigation expansion has for centuries been an instrument of agricultural growth and is now an important item of policy planning for both public and private investment, but its efficacy too depends on rainfall though perhaps not exactly when and where the water is applied. Supply of water to a crop in any region is therefore determined not just by the local rainfall but also supplies from rivers, canals and reservoirs fed by precipitation at earlier times and elsewhere, specifically in the mountains. Finally, crops differ in their moisture requirements. The demand for water of any one crop is variable across its growth cycle. Many crops are much more modest in their water requirements than others. So, increased rainfall is not necessarily conducive to greater production and efforts on draining the soil are critical in many cases. Further, with greater water availability from any source, such crops are likely to give way to more water demanding crops so far as the latter are also more lucrative.

The objective of this paper is to understand, on the basis of modelling, the rainfall-production nexus for the two major food grain crops in India namely, Rice and Wheat, identify the spatial and temporal dimensions of rainfall as the driving factor and to describe the effects as favorable or adverse for the crops. Wheat cultivation, undertaken in winter months making up the 'rabi' season in India, is largely concentrated in Northern India with some presence in central India while acreage under 'kharif' crop Rice in the monsoon season, is far more well- distributed throughout the country. Rice is grown also in the rabi season with irrigation in southern and eastern parts of the country such as West Bengal and eastern Uttar Pradesh.

This paper reports model results of kharif Rice and rabi Wheat in four major growing states each (i) West Bengal, Uttar Pradesh, Punjab and Andhra Pradesh (pre-bifurcation including Telangana) for Rice and (ii) Uttar Pradesh, Madhya Pradesh, Punjab and Haryana for Wheat. The select states contribute nearly $78 \%$ and $46 \%$ of all India production of Wheat and Rice respectively (Table A1). Other than West Bengal and Andhra Pradesh, which are primarily Rice growing, all the other study states rotate Rice with Wheat leaving a short intervening window between a harvest and a sowing season. The focus of the discussion is the spatial and temporal dimensions of rainfall impact on production signifying the water dynamics via interstate river flows, reservoirs, canals and water tables as reflected by the model results. With developments in seed technology sowing a crop may be delayed or advanced if conditions are not suitable though the rescheduling may disturb the next crop calendar. Wheat thrives in well-drained friable soils (clay, loam). Moderately low temperature and rainfall not more than annual $100 \mathrm{~cm}$ create the ideal climate. It can withstand frosts and also overcome poor rainfall if irrigation is available. Rice is grown on a wide variety of soils but it needs hot and humid atmosphere with good rainfall not less than $100-200 \mathrm{~mm}$ per growing month. Rainfall at harvest is harmful for both crops.

\section{WATERSCAPE OF INDIA'S AGRICULTURE}

This theoretical section tries to answer why rainfall at a broader dimension beyond the space and time of crop production under investigation should be of research interest for its impact of crop area and productivity. The reason can be explored in the biological demands of varied crops, the spatial clustering and distribution of crops in land area and the system of water distribution driven by geography, investment, interventions and administration.

\subsection{Crops and Water}

Crops need optimal water to germinate, live and grow and to draw necessary nutrients from soil. Not surprisingly, rainfall, including the performance of monsoon, has always been considered a most important driving factor of food production. However, the average rainfall statistic in a year or the main monsoon season says little. Because crops have specific requirements of water at different times, control on water supply is important for agriculture.

Planting of a crop is contingent of availability of soil moisture in adequate amounts at the sowing time that can come from current or recent rainfall or irrigation of the land while crop yield is sensitive to the sufficiency of water at all stages of growth starting from sowing to harvest. Late onset of monsoon, deficient seasonal rainfall, early end to monsoon season and shortage of post-monsoon rainfall (north-east monsoon, cyclones, depressions, western disturbances) all have adverse effects on either area or yield or both. The moisture stress compromises production. Many crops, on the contrary, are actually hurt by excess water relative to their requirements at any stage of growth. Water abundance can arise from unusually heavy rainfall at the time or from an excessively moist soil, soaked with water from past rainfall or irrigation that has not been properly drained and above all, from a floods which is much more devastating. Floods are related to both current and past rainfall in conjunction with the quality of river water administration. Therefore, crop production especially with climate change, is profoundly impacted by infrastructurebacked water management at the field level, community level and at the macro-level.

Constrained by soil composition and other geographical features, crop acreages are not uniformly distributed across the country, but even within a state that grows the crop, clustering may be observed. Indian climate is marked by remarkable heterogeneity so that weather condition at the specific site of crop clustering is of relevance for a crop rather than a broadbased average. Table A1 which lists the districts accounting for $60 \%$ of production of Rice and Wheat however suggests fair dispersion within growing states. Weather data is officially reported representatively for meteorological subdivisions (MET) which are not sharply demarcated by political state boundaries.

Some METs overlap the boundary and cover two or more contiguous states while some states have enough climatic diversity to accommodate two or more METs. Due to the spatial dispersion of hydrology, the trans-state character of climatic units and the varied concentration of crops within a state, rainfall in a MET (see map in Figure 1) is more determinative of crop production than the averages of states that are political and administrative constructs. The study states Uttar Pradesh, Madhya Pradesh and West Bengal are described by two METs each, Andhra Pradesh by three and Punjab, Haryana have one each but climatic overlaps between a neighboring state and a MET are possible (see Table A4). 
Rainfall in the study unit or its proximity is not the only source of water for crops. Irrigation is a powerful supplement to rainfall that motivated construction of public infrastructure Irrigation harnesses water from rainfall even in METS other than the border of study state for redistribution. While METS located upstream is more decisive for its effect on river dynamics, shortage or surplus of rainfall at locations lateral or downstream can also matter if they are connected hydrologically as explained in the next sub-section.

Although water shortage is highlighted in the political economy of India's agriculture, in reality water requirement of most crops is moderate and moisture beyond a level can prove damaging. Moreover, water supply to a crop is temporal, not only confined within the growing season. It must factor in pre-season rainfall and also past rainfall that recharge ground water, tanks, water harvesting mechanisms and can be stored in reservoirs. Crop preference while sowing depends on not only site-specific and contemporary rainfall but also rainfall in other METs and past seasons depending on geography, water management protocols and land use policy and the effect can be both favourable and adverse. Since farmers would also weigh economic benefits from among crops in choice, superior water availability may draw limited land and possibly also other resources towards more lucrative crops in preference to other crops.

\subsection{Hydrology of River basins and the River dynamics}

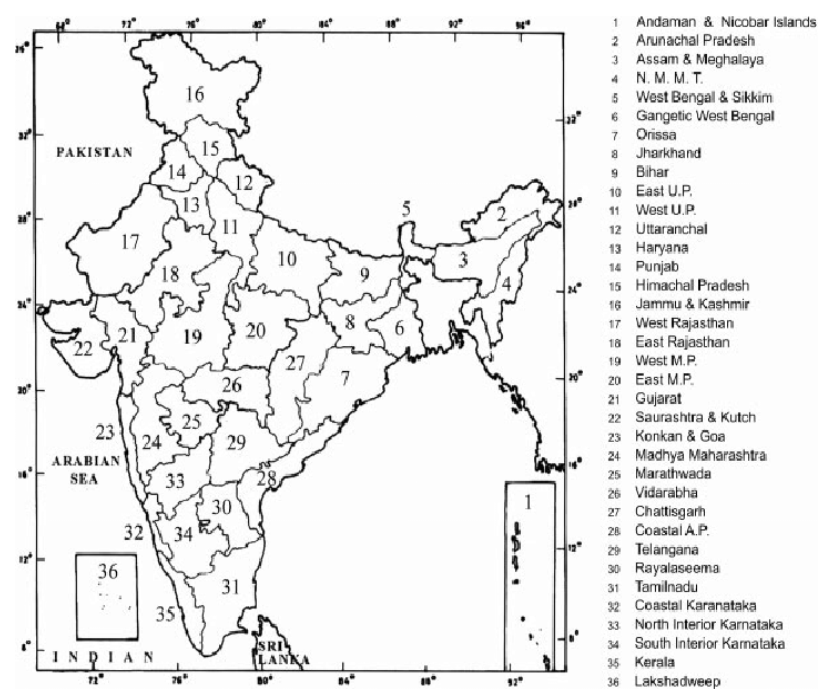

Figure 1: Meteorological sub-division map of India

River basins, being influenced by human activities in many ways, have caught research attention in the context of land use changes and climate change that may impinge on mountain water flows (Chang and Franczyk, 2008, Errikson et al 2009, Tiwari 2008). Users in downstream areas are concerned about upstream land use and water management practices. Effects of land use decisions in the mountains on downstream developments can be mixed but are claimed to be limited, the associated THED $^{3}$ hypothesis being highly critiqued in literature (Flugel and Bartosh, 2011, Douglas and Swank, 1975, FAO and CIFOR, 2005, Nepal et al., 2014, Ghosh et al., 2016). Forests however increase water holding capacity of soil, delaying and slowing floods though beyond a point heavy rainfall can cause more disastrous floods. Integrated land and water resource management (ILWRM) for planning river basin based on knowledge of upstream downstream linkages has been advocated (Nepal 2014).

Nepal $(2012,2014)$ divided a river basin into three parts namely Source zone (SZ), Transition Zone (TZ) and Floodplain zone (FZ). The SZ located at upper altitudes in the mountains is marked by glaciated geography, rapid dynamics with erosion and the rise of numerous streams that confluence to form the river. The SZ is most affected by Global Warming $(\mathrm{GW})$ that has anthropogenic roots. GW is believed to further hasten the hydrology of rivers creating shortages in upstream areas and floods at lower ends. In the TZ the effect of the materials carried down and the land use decision of human being, mostly related to forest versus farmlands, begin to shape the form, direction and velocity of the river as more tributaries merge with it to deliver more water on the lower plains. The upper reaches of the rivers are sites of many structures of river valley projects including hydroelectric plants. The FZ is where the sediments settle, river slows down under its own volume and the flatter topography and even divides into channels but this zone shows more variety and can be further sub-divided beyond what Nepal (2012) shows. Salinity, deltas and mangrove of the region near the mouth of a river have strong implications for biodiversity, agriculture and poverty.

\subsection{Water sharing}

Dams, barrages embankments and reservoirs make up the river management infrastructure of India in tune with the geography (see Figure 2). The river-flow is blocked, stored, divided, diverted and delayed by conscious human action. Water managers have the ability to distribute water spatially and over time and deliver it to agriculture via canals. River water seeps from its channels to recharge ground water, percolate into tanks and to evaporate into the water cycle. Hydropower generated by the river projects energize pumps to recover the ground water for irrigation. Water is managed not only to irrigate but also to meet urban water needs. Greater control over water vested with managers at upstream location often leads to conflicts and water sharing arrangements. The Upper Ganga canal system was one of the first structures built in upstream Uttar Pradesh in 1848. The western Yamuna canal dates back to fourteenth century and was remodeled by the British in 1870s. Figure 3 shows the intensely managed river water system of India.

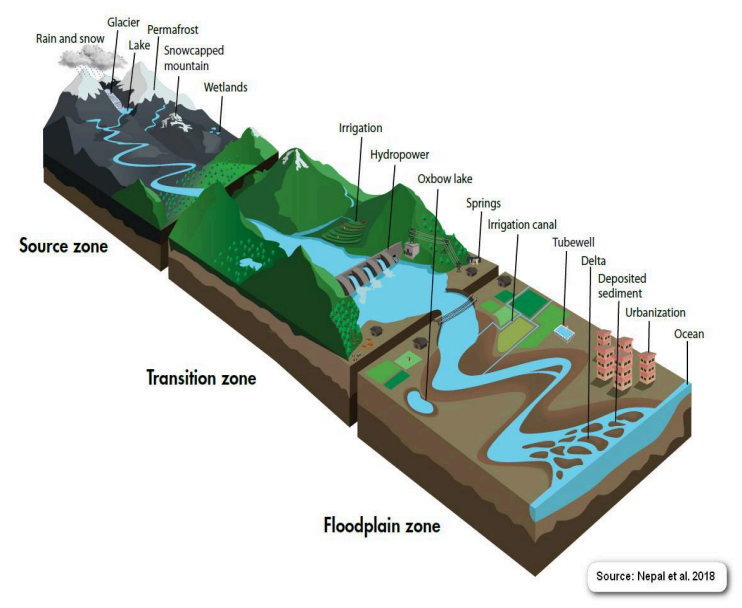

Figure 2: Schematic diagram of a river corridor showing three zones and their upstream-downstream relationships

\footnotetext{
${ }^{3}$ Theory of Himalayan Environmental Degradation
} 
Water is a vital resource for life, livelihood and food security and therefore in India, political significance of water is immense. Northern part of the subcontinent is drained by major rivers Ganga, Yamuna, Indus and Brahmaputra all of which arise in the Himalayas. Indus and Brahmaputra's have their sources in Tibet, region of China. The mountains are areas of glacier melt, head waters and erosion. Numerous tributaries join the rivers such as Gandak, Ghagra, Kosi with Ganga, Dibang, Lohit, Subansiri and Teesta with Brahmaputra and Ravi, Beas, and Sutlej with Indus. The Yamuna meets the Ganga in Uttar Pradesh and Brahmaputra meets Ganga in Bangladesh before the combined channel reaches the Bay of Bengal.

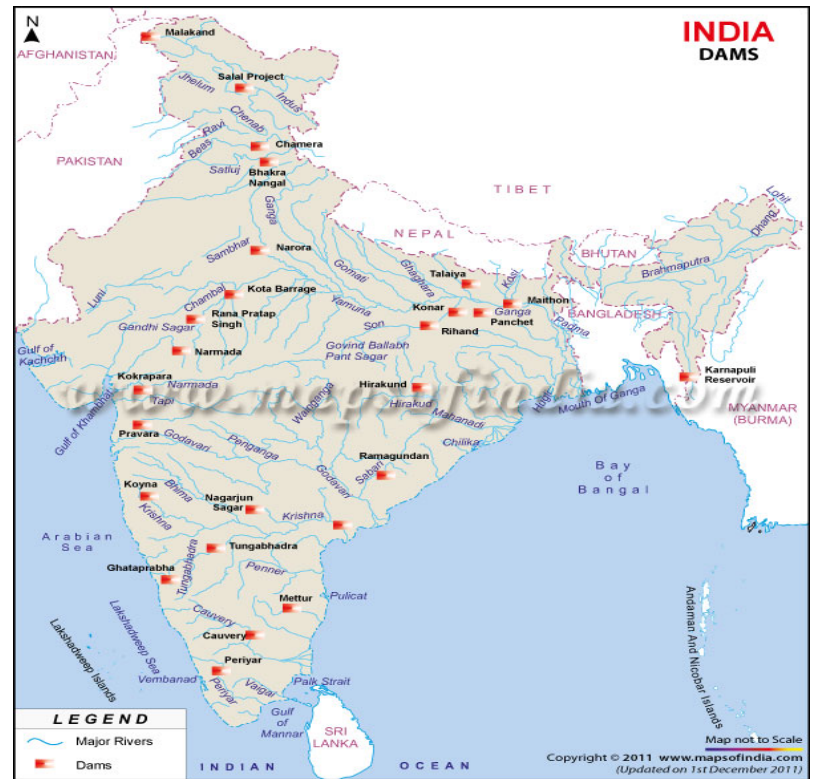

Figure 3: Dams and Rivers map of India

Together, the trans-boundary rivers of North India cover multiple countries. In south India, rivers are not snow-fed so that the base-flow in dry season is meagre and the states they drain face seasonal water deprivation. Though there is no international dimension in these basins, their inter-state character never fails to raise discontent about water distribution despite centralized adjudication by tribunals, water sharing agreements supervised by the judiciaries and administrative inter-state water boards so that the downstream states in a basin are not discriminated in favor of source state.

Water use for agriculture and water to meet competitive civic needs, have created many uprisings in recent times taking political hues (Bhaduri 2016, Sangameswaran, 2009). In 2016 a caste-based violent protest representing a conflict between irrigation demands of the Haryana state versus Delhi's drinking water needs caused a breech on the Munak canal which start at Hathinikund (operational from 2002) from the western Yamuna canal. Although Delhi invested in lining the canal, Haryana with its alluvial plains and heavy investments on infrastructure has greater control over the water flow. Interstate water disputes arise over Ravi-Beas basin among Punjab, Haryana, Rajasthan and Delhi, attributed to legal deficiency and other unresolved tensions (Ballabh, 2008). Inappropriate cropping pattern, in particular, growing water guzzling Rice and sugarcane with the support of free electricity in Punjab and Haryana and absence of water pricing, has been associated with a perverse relation between land productivity and irrigation water productivity (IWP) so that less irrigated states are observed to have high IWP despite low land productivity compared to more endowed states (Sharma et al., 2018).The Haryana episode of 2016 is associated with agrarian distress even while waterlogging and salinity are serious problems of the state. Tamilnadu is highly reliant on supplies from upstream Andhra Pradesh and Karnataka to deliver water in Chennai (Madras) City drawing from Krishna, Cauvery and Godavari rivers but this demand creates pressure on the other states that also face water scarcity.

Regulation of water flow is a critical function of the administration and its effect can be powerful on agriculture. The management has to take account of the volumes of water received, stored and in demand from various user including farmers. Inefficient management can not only cause water scarcity in certain areas leading to conflicts but also devastating floods when the reservoir level is not managed optimally. The Kerala flood in August 2018 was attributed to excess release from the reservoir which was already in full capacity prior to unusually heavy rainfall (Bhadbhade, 2018) although the Central Water Commission (CWC) advocated construction of more dams as a solution. Devastating floods are also witnessed in northern India such as in Uttarakhand 2013 and the regular Kosi flood of Bihar but the roots of this malaises can be traced also to trans-border rainfall. Treaties for river water sharing such as with Bangladesh and Pakistan are critical diplomatic issues.

\section{METHODOLOGY AND DATA}

The model used is econometric in nature allowing for economic, infrastructural and climatic variables to influence production and is based on the pattern of interactions observed from results generated by past data available from government sources. The spatial unit of analysis is a state but MET level weather data is considered explanatory variables. The model allows for the possibility that rainfall in state level METs as well as a different MET can be of importance.

\subsection{Equations}

The typical structural econometric model can be presented as

\section{Area Equation:}

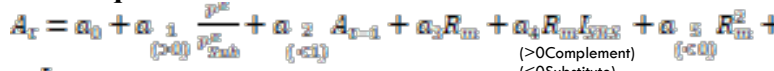

$$
\begin{aligned}
& a_{\mathrm{g}} I_{\text {ming }}
\end{aligned}
$$

\section{Yield Equation:}

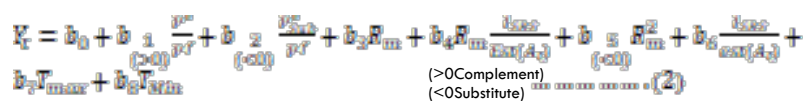

Where $P^{e}=$ Expected Price (Previous harvest month prices (Kharif/Rabi) and MSP $P^{J}=$ Price of Fertilizer

$R_{\mathrm{m}}=$ Sowing/pre-sowing/growing month's rainfall $\mathrm{Sub}=$ Substitute Crop in that season in the state $\mathrm{SRS}=$ Source wise irrigation

$\mathrm{T}=$ Temperature, maximum and minimum are average of daily maximum and minimum.

The econometric model estimates the relation between acreage (in hectare) and crop yield (as $\mathrm{Kg}$ per hectare) both considered as dependent variables on the one hand and explanatory variables prices, irrigated area by sources and weather variables rainfall and temperature on the other. The model is represented 
by equations (1) and (2) for acreage and yield respectively which also indicate the signs of parameter (effects of variables) as expected using conditions for intuitive reasoning such as a positive response to economic incentives $\left(\mathrm{a}_{1}>0\right)$ and $a$ mathematical stability $\left(\mathrm{a}_{2}<0\right)$ of the model. Time series data on annual crop area, yield and area under irrigation, monthly data on wholesale prices of crops and fertilizers (indices), annual MSPs, monthly rainfall and fortnightly temperature in the 36 METs of the country and are obtained from official sources (DES, Website, IMD, Website). Given the highly dynamic situation in the country, the sample period used for model estimation is advanced for FASAL each year as recent data becomes available while observations from remote years are dropped, to avoid relational obsolescence. The models are tested successively in terms of diagnostics (t-statistics, R-bar-square, DW-statistics, stationarity of the error and the estimation error). While the expectation is to obtain positive responses of production to crop prices (or revenues) relative to substitute crops, identified using state level crop calendars or to fertilizer price, the effect of weather is left open for the data to determine except that excess rainfall (squared rainfall) is expected to be harmful. The model is linear except for the quadratic effect of rainfall and interaction between irrigation and rainfall. The model is tried with various specifications considering the marketing seasons of crops, rainfall in alternative months in the METs and irrigation of different types while leaving flexibility for timing and location of rainfall (using geographical, canal and river maps).

The period of rainfall is divided into sub-periods (i) Pre-season rainfall: Mostly determining irrigation and flood effects, (ii) Sowing window rainfall: determining the soil moisture at planting time, (iii) Growing time: water to meet needs of maturation, flowering and ripening, and (iv) Late season: water availability at maturity and harvesting that may not help production and is more likely to cause damage unless the cropping cycle is delayed.

In the equation for area the price is expressed in relation to possible substitute crops vying for area. Crop price is represented not just by previous harvest season price because the market price to be fetched is yet unknown but also by the MSP which is announced publicly and average is taken if both are found significant. For the yield equation, the crop price is taken relative to price of fertilizer, the main input bur relative prices of alternative crops that compete for resources are additionally considered. Irrigated area under sources canals, tubewells, tanks and other sources and under all sources together are considered for both equations but in the yield equation the irrigated area is deflated by the crop area estimated from the area equation in the combined model. Rainfall variable is considered in isolation or as interaction with the irrigation variables because the outcome of irrigation depends on the rainfall in specific locations and times. In the yield function maximum and minimum temperatures of the entire season are considered.

\section{RESULTS}

Tables A2 and A3 present the lists of the rainfall variables that are found to be strong influences on area and yield of the crops in each study state during the sample period. In addition, the prices that matter are also indicated. Estimated equations generate coefficients that are statistically significant for all the variables that are listed. The estimated and discussed effects are incremental (marginal) of variables. A positive coefficient indicates a favorable effect on the dependent variable while an adverse effect is suggested by a negative coefficient. The results reported therefore summarize cases in which the variables have high probability of having a positive or a perverse relation with area and yield although the effect of any variable may not be the same in both equations of a crop. All estimated equations showed good fit with R-bar square uniformly exceeding 90\%. Plotted graphs of observed and estimated values of the dependent variables show high degree of concordance of movement in all cases.

Presence of growing season (as specified) rainfall especially within the state (Andhra Pradesh) in the acreage equation and of late season in the yield equation with positive effect in most cases suggest that crop cycles are not rigid and can be delayed. Besides in some states like West Bengal and parts of Andhra Pradesh multiple successive rice crops are grown in the monsoon season. In Punjab the area and yield of Rice and Wheat are least affected by rainfall within the state.

The role of rainfall in a downstream or a distant state would indicate water sharing obligations but it is not highly evident in findings. Although much of the rainfall effects come from bordering plain states that share climatic commonality, the presence of hill states and only a few non-contiguous METs underline the benefits of surface irrigation, water logging problem and possibility of floods arising from insufficient water management. Economic variables namely, MSP and market price of crop, price of substitute crops and fertilizer are uniformly significant effects on production. For Wheat, Sugarcane, Moong and Rice emerge as the substitute crops in Uttar Pradesh, Potato in Punjab and Gram in Madhya Pradesh. No particular substitute crop for Wheat is identified for Haryana. Substitute crop for sowing Rice are found to be Jowar and Onion in Uttar Pradesh, Jute, Arhar and Urad in West Bengal, Moong in Punjab and Bajra and Urad in Andhra Pradesh highlighting the significance of pulses and coarse cereals in the cropping decisions. Growing season temperature impacts on yield in some cases and although effect of higher temperature can be favorable for Rice but adverse for Wheat in late season

\subsection{Kharif Rice}

Rainfall variable in the METs located within the study states are expected to determine the area and yield of the crops. State level sowing season rainfall is a powerful positive effect on Rice planting in Uttar Pradesh where no effect of its pre-season rainfall is seen but in West Bengal pre-season rainfall in both the METs of the state helps to increase Rice acreage. In Andhra Pradesh pre-season and sowing season rainfall in all 3 METs of the state and growing season rainfall in two METs have positive effects on acreage. Rainfall in Punjab has no effect on acreage in Punjab.

Rainfall in the hills affect Rice acreage but with few expectations the effects are hardly beneficial. West Bengal's pre-season rainfall enhances its acreage. Negative effects are observed of rainfall in states Uttarakhand, Himachal Pradesh, on Uttar Pradesh and Punjab. Among other plain states rainfall beyond study zone in $\mathrm{BH}, \mathrm{JH}$ and ERJ appear influential in Uttar Pradesh, rainfall in $\mathrm{CH}$ on West Bengal, rainfall in ERJ on Uttar Pradesh and Punjab and METs OR and WMP on Andhra Pradesh.

In Uttar Pradesh, sowing and growing season state rainfall is favorable to yield along with that in eastern neighbors $\mathrm{BH}$ and EMP. In Andhra Pradesh sowing and growing season rainfall in 
all 3 METs (CAP, TL, RY) helps to improve yield, which is also sensitive to rainfall in neighboring SIK and OR and distant KG. On the contrary, in both West Bengal and Punjab the state rainfall has no favorable effect on yield but rainfall in $\mathrm{BH}$, ASM, JH located in neighboring states helps to improve yield in West Bengal and that of neighboring HCD and WRJ in Punjab. In fact, rainfall in both mountainous and Gangetic parts of West Bengal (HWB, GWB) hurts Rice yield. Similarly, rainfall in PJ appears adverse for Rice yield in Punjab.

Pre-season rainfall of eastern neighbor $\mathrm{BH}$ and sowing season rainfall in western neighbor PJ are adverse for yield in Uttar Pradesh. Pre-season rainfall in $\mathrm{CH}$ and $\mathrm{JH}$ and sowing rainfall in OR, HWB and GWB and growing season rainfall on GWB hurt rice yield in West Bengal. Rainfall in WUP, HCD and growing season rainfall in PJ are harmful for yield in Punjab, pre-season rainfall of NIK, late season rainfall TL and distant KG are adverse for yield in Andhra Pradesh. Negative effect of hill rainfall (HP, JK) in Uttar Pradesh, HWB in West Bengal and UT and HP in Punjab are observed reflecting the poor efficacy of surface water management. Rainfall has a widespread influence on Rice production which is impacted by pre-season, sowing window, growing and late season rainfall. Hill rainfall is influential but is rarely beneficial except for a favorable effect on acreage in West Bengal. The presence of late season rainfall indicates flexibility of the crop calendar.

\subsection{Wheat}

In all the state cases but Punjab, area and, to a more limited extent, yield is influenced by pre-season rainfall in the state and elsewhere. Wheat acreage in Uttar Pradesh is favored by preseason rainfall in the state (WUP) and in Madhya Pradesh by its pre-season and sowing window rainfall and also the growing season rainfall in eastern part (EMP) of the state. Similarly, preseason and growing season HCD rainfall encourages planting in Haryana. For Wheat yield too, pre-season and sowing season rainfall of the state is good for Uttar Pradesh. In Madhya Pradesh state rainfall at all stages up to late season is good for yield though the spatial distribution is important given adverse effects arise also. In Haryana, while pre-season rainfall is good for the yield, sowing season rainfall is not. In Punjab, unfavorable effect of seasonal rainfall of a neighboring MET (HCD) is seen on yield while sowing season rainfall of both PJ and HCD deters sowing in Punjab. Wheat in Punjab and Haryana benefit from irrigation harnessed from managed past rainfall but the local seasonal rainfall scarcely helps.

Rainfall in the hill states is important but like for Rice, mostly harmful, observed as the negative effects for Wheat planting in three states Punjab, Uttar Pradesh and Haryana. Several instances of adverse effect on yield are also seen. Pre-season hill rainfall has no impact on Wheat acreage in Uttar Pradesh. Positive effect of hill rainfall is seen on acreage in Haryana and Uttar Pradesh. Pre-season rainfall in UT hurts yield in Punjab and Haryana.

Cross-state dissimilar rainfall effects are also observed. Preseason rainfall in the two western METs in Madhya Pradesh has both positive and negative effects on Wheat area in Uttar Pradesh, but rainfall in EUP is good for sowing in Madhya Pradesh. Sowing in Punjab is hurt by sowing season rainfall in PJ and HCD which however help in sowing in Haryana possibly reflecting Haryana infrastructure. Rainfall in Uttar Pradesh and Madhya Pradesh influence acreage in each other but the effect depends on the timing. Wheat yield in Uttar Pradesh benefits from rainfall in both Uttar Pradesh and Madhya Pradesh but yield in Madhya Pradesh is not sensitive to rainfall in Uttar Pradesh. In addition to the study states, Wheat yield in Madhya Pradesh is influenced by rainfall in Maharashtra (VDB, MMH) and in eastern states $(\mathrm{CH}, \mathrm{JK})$ while rainfall in Rajasthan (ERJ) impacts on Haryana crop yield.

\section{SUMMARY}

Area and Yield are determined by rainfall not necessarily in the states and in the neighboring METs but also in hills and upstream states but remarkably, the role is not always favorable. Negative effect of incremental rainfall can indicate excess moisture, poor drainage, diversion to more profitable crops and floods. Crop cycle, it appears is not rigid and the growing cycle can be delayed. In Punjab acreage and yield of both Rice and Wheat are least effected by the state's rainfall. Role of rainfall in downstream or distant states which would suggest water sharing obligation is not outstanding in the results. Although much of the rainfall effect come from bordering plain states with commonality of climate, the effect of hill rainfall and a few non-contiguous METs shows the presence of irrigation impact and possibility of floods due to poor water management.

Both MSP and market price of the study crop and the price of fertilizer are influences on production. Temperature effects are also observed in yield equations but the effects can be favorable as in Rice and adverse as for Wheat especially in the late season. Results for the ample period suggest that forecast methods and the government's water policy can gain efficiency by considering the spatial and temporal impacts of rainfall on production.

\section{REFERENCES}

Ballabh, Vishwa, 2008. Governance of Water: Institutional Alternatives and Political Economy. Publication- Sage New Delhi.

Bhadbhade, Neha, 2018. Dams did exacerbate Kerala's floods. Business Line, Thursday September 20.

Bhaduri, Amita, 2016. Two states, a canal and a river: India Water portal, Article on $17^{\text {th }}$ May.

Chang, H. and Franczyk, J., 2008. Climate change, land-use change, and floods: toward an integrated assessment. Geography Compass, Vol 2(5), September, pp. 1549-1579.

Directorate of Economics and Statistics (DES), Website. Department of Agriculture, Cooperation and Farmers Welfare, Ministry of Agriculture and Farmers Welfare, Government of India. https://eands.dacnet.nic.in/Default.htm

Douglass, J.E., Swank, W.T., 1975. Effects of management practices on water quality and quantity: Coweeta Hydrologic Laboratory, North Carolina. In: Municipal Watershed Management Symposium Proceedings. USDA Forest Service Gen. Tech. Report NE-13, Northeastern Forest Experimental Station, pp. 1-13.

Eriksson, M., Shrestha, Xu, J., Vaidya, A. B., R. A., Nepal, S., \& Sandstrom, K., 2009. The changing Himalayas: Impact of climate change on water resources and livelihoods in the Greater Himalayas. Kathmandu: ICIMOD. 
FAO, CIFOR, 2005. Forests and floods: drowning in fiction or thriving in facts? Center for International Forestry Research and Food and Agriculture Organization of the United Nations, Bogor and Bangkok.

Flügel, W.A. and Bartosch, A., 2011. Analysis of present IWRM in the Upper Brahmaputra and the Upper Danube River Basins. Adv Sci Res 7, pp. 47-54.

Ghosh, Nilabja, Tripathi, A.M. Rajeshwor, Verma, R. and Sankar. K. Sankar, 2016. Problems of water and food insecurity in the Indian part of the Kosi river basin: A study on agriculture. Institute of Economic Growth Delhi, Report submitted to International Centre for Integrated Mountain Development (ICIMOD), Kathmandu, Nepal.

India Meteorological Department (IMD), Website.

Ministry of Earth Science, Government of India. http://www.imd.gov.in/Welcome\%20To\%20IMD/Welcome.ph p

Nepal, Santosh, Avash Pandey, Arun B. Shrestha, and Mukherji, Aditi, 2018. Revisiting Key Questions Regarding Upstream-Downstream Linkages of Land and Water Management in the Hindu Kush Himalaya (HKH) Region. Working Paper 21, Himalayan Adaptation, Water and Resilience Research (HI-AWARE), Kathmandu, Nepal, November.

Nepal, Santosh, Wolfgang-Albert Flügel and Arun Bhakta Shrestha, 2014. Upstream-downstream linkages of hydrological processes in the Himalayan region. Ecological Processes 2014 $3: 19$.

Nepal, Santosh, 2012. Evaluating Upstream-Downstream Linkages of Hydrological Dynamics in the Himalayan Region. $\mathrm{PhD}$ thesis. Published. Friedrich Schiller University Jena, Germany.

Sangameshwaran, Priya, 2009. Water: Perspectives of Governance. Economic \& Political Weekly, January 10, pp. 37.

Sharma, Bharat R., Gulati, Ashok, Gayathri Mohan, Manchanda, Stuti, Ray, Indro, and Upali Amarasinghe, 2018. Water Productivity Mapping of Major Indian Crops. NABARD and ICRIER.

\section{APPENDIX}

\begin{tabular}{|c|c|c|}
\hline \multicolumn{3}{|c|}{$\begin{array}{l}\text { Table A1: Study States and major districts producing Rice and Wheat } \\
(2015-16)\end{array}$} \\
\hline States & $\begin{array}{l}\text { Production } \\
\text { Share in India } \\
\text { total }(\%)\end{array}$ & $\begin{array}{l}\text { Districts accounting for production of } \\
60 \% \text { or more of State total }\end{array}$ \\
\hline \multicolumn{3}{|r|}{ Wheat } \\
\hline $\begin{array}{l}\text { Uttar } \\
\text { Pradesh }\end{array}$ & 29.1 & $\begin{array}{l}\text { Hardoi, Shahjahanpur, Bulandshahr, } \\
\text { Budaun, Aligarh, Azamgarh, Mathura, } \\
\text { Bareilly, Kheri, Pilibhit, Jaunpur, } \\
\text { Mainpuri, Sitapur, Unnao, Siddharth } \\
\text { Nagar, Barabanki, Bahraich, Ghazipur, } \\
\text { Fatehpur, Maharajganj, Rampur, } \\
\text { Allahabad, Gonda, Gorakhpur, } \\
\text { Sambhal, Deoria, Agra, Etah, } \\
\text { Ambedkar Nagar, Saharanpur }\end{array}$ \\
\hline Punjab & 17.4 & $\begin{array}{l}\text { Sangrur, Bathinda, Ludhiana, Patiala, } \\
\text { Muktsar, Fazilka, Firozepur, } \\
\text { Gurdaspur, Amritsar, Tarn Taran }\end{array}$ \\
\hline Madhya & 20.0 & Hoshangabad, Sehore, Ujjain, Dewas, \\
\hline
\end{tabular}

\begin{tabular}{|c|c|c|}
\hline Pradesh & & $\begin{array}{l}\text { Raisen, Vidisha, Harda, Chhindwara, } \\
\text { Dhar, Indore, Datia, Gwalior, Bhind, } \\
\text { Khargone, Guna, Jabalpur, Ashoknagar }\end{array}$ \\
\hline Haryana & 11.3 & $\begin{array}{l}\text { Sirsa, Hisar, Fatehabad, Bhiwani, Jind, } \\
\text { Kaithal, Karnal }\end{array}$ \\
\hline \multicolumn{3}{|r|}{ Rice } \\
\hline $\begin{array}{l}\text { Uttar } \\
\text { Pradesh }\end{array}$ & 12.0 & $\begin{array}{l}\text { Barabanki, Shahjahanpur, Pilibhit, } \\
\text { Maharajganj, Kheri, Siddharth Nagar, } \\
\text { Azamgarh, Chandauli, Sitapur, } \\
\text { Ghazipur, Bareilly, Bahraich, Hardoi, } \\
\text { Rampur, Bulandshahr, Allahabad, } \\
\text { Gonda, Jaunpur, Rae Bareli, Ambedkar } \\
\text { Nagar, Pratapgarh, Moradabad, } \\
\text { Gorakhpur }\end{array}$ \\
\hline $\begin{array}{l}\text { West } \\
\text { Bengal }\end{array}$ & 15.3 & $\begin{array}{l}\text { Medinipur West, Purba Bardhaman, } \\
\text { Birbhum , Murshidabad, Medinipur } \\
\text { East, Bankura, Paraganas South }\end{array}$ \\
\hline Punjab & 11.3 & $\begin{array}{l}\text { Sangrur, Ludhiana, Patiala, Moga, } \\
\text { Firozepur, Muktsar, Jalandhar, } \\
\text { Bathinda, Amritsar }\end{array}$ \\
\hline $\begin{array}{l}\text { Andhra } \\
\text { Pradesh }\end{array}$ & 7.2 & $\begin{array}{l}\text { West Godavari, East Godavari, SPSR } \\
\text { Nellore, Krishna }\end{array}$ \\
\hline
\end{tabular}

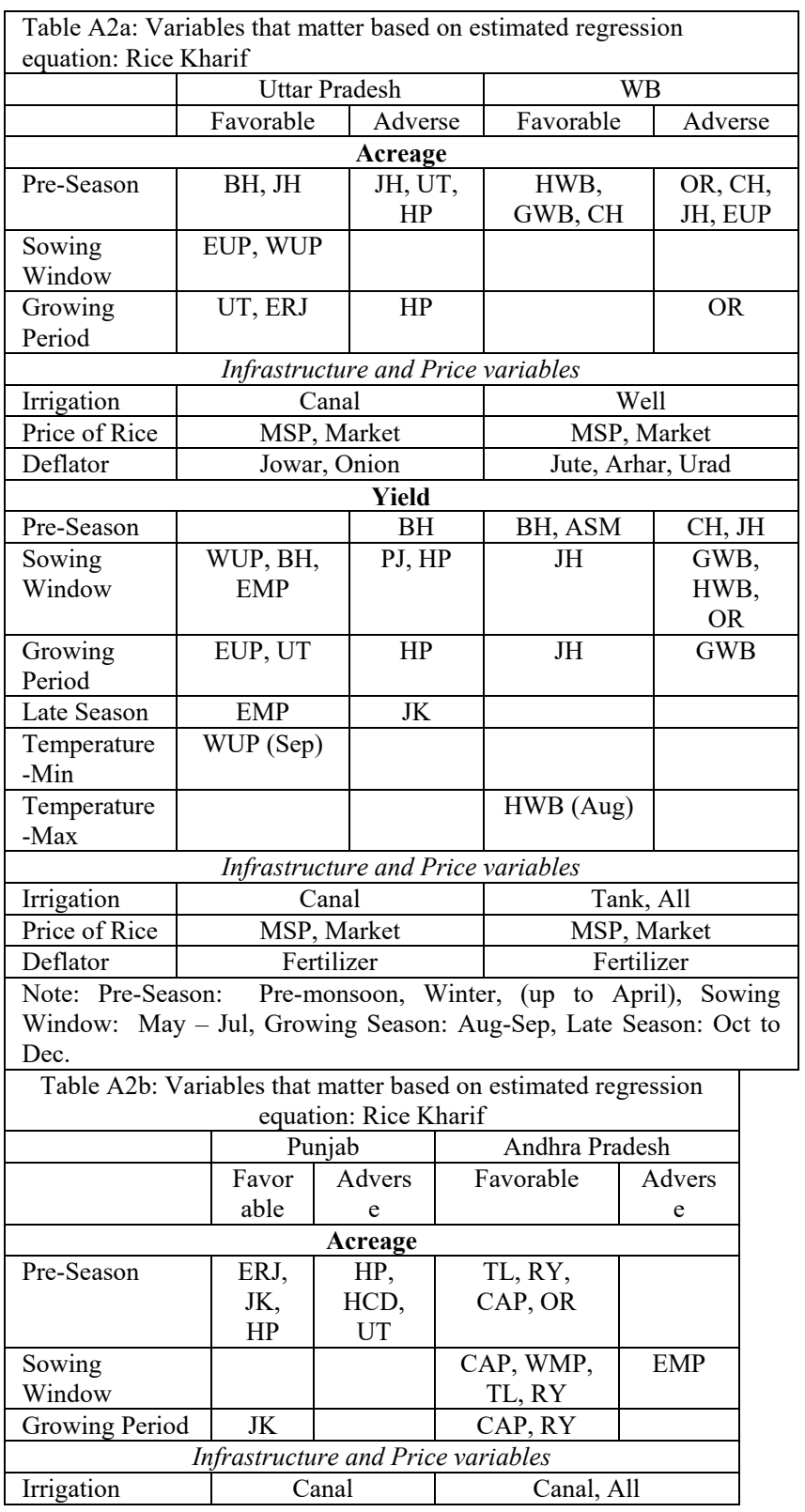


The International Archives of the Photogrammetry, Remote Sensing and Spatial Information Sciences, Volume XLII-3/W6, 2019 ISPRS-GEOGLAM-ISRS Joint Int. Workshop on “Earth Observations for Agricultural Monitoring”, 18-20 February 2019, New Delhi, India

\begin{tabular}{|c|c|c|c|c|}
\hline Price of Rice & \multicolumn{2}{|c|}{ MSP, Market } & \multicolumn{2}{|c|}{ MSP, Market } \\
\hline Deflator & \multicolumn{2}{|c|}{ Moong } & \multicolumn{2}{|c|}{ Bajra, Urad } \\
\hline \multicolumn{5}{|c|}{ Yield } \\
\hline Pre-Season & HCD & $\begin{array}{c}\text { UT, } \\
\text { WUP, } \\
\text { PJ, HP }\end{array}$ & $\begin{array}{c}\text { SIKR, OR, } \\
\text { KG }\end{array}$ & NIKR \\
\hline $\begin{array}{l}\text { Sowing } \\
\text { Window } \\
\end{array}$ & & HCD & CAP, TL & \\
\hline Growing Period & $\begin{array}{l}\text { WRJ, } \\
\text { JK }\end{array}$ & PJ & CAP, RY & \\
\hline Late Season & & & $\mathrm{OR}$ & $\mathrm{TL}, \mathrm{KG}$ \\
\hline $\begin{array}{l}\text { Temperature- } \\
\text { Min }\end{array}$ & & & & \\
\hline $\begin{array}{l}\text { Temperature- } \\
\text { Max }\end{array}$ & & & & $\begin{array}{c}\text { TL } \\
\text { (Oct) }\end{array}$ \\
\hline \multicolumn{5}{|c|}{ Infrastructure and Price variables } \\
\hline Irrigation & \multirow{2}{*}{\multicolumn{2}{|c|}{$\begin{array}{c}\text { Canal } \\
\text { MSP }\end{array}$}} & \multicolumn{2}{|c|}{ Canal, Tank, All } \\
\hline Price of Rice & & & \multicolumn{2}{|c|}{ MSP } \\
\hline Deflator & \multicolumn{2}{|c|}{$\frac{\text { MSP }}{\text { Fertilizer, Maize }}$} & \multicolumn{2}{|c|}{ Fertilizer } \\
\hline
\end{tabular}

\begin{tabular}{|l|c|c|c|c|}
\hline \multicolumn{5}{|c|}{ Table A3a: Variables that matter based on estimated regression } \\
equation: Wheat Rabi
\end{tabular}

\begin{tabular}{|c|c|c|c|c|}
\hline \multicolumn{5}{|l|}{ Wheat } \\
\hline Deflator & \multicolumn{2}{|c|}{ Gram } & \multicolumn{2}{|c|}{ All } \\
\hline Pre-Season & $\begin{array}{l}\text { EMP, } \\
\text { MMH }\end{array}$ & $\begin{array}{c}\text { WUP, } \\
\text { WMP, } \\
\text { CH }\end{array}$ & $\begin{array}{c}\text { HCD, HP, } \\
\text { PJ, JK }\end{array}$ & ERJ \\
\hline $\begin{array}{l}\text { Growing } \\
\text { Window }\end{array}$ & $\begin{array}{l}\text { WMP, } \\
\text { VDB }\end{array}$ & $\begin{array}{c}\text { EMP, } \\
\text { MMH, } \\
\text { SK }\end{array}$ & PJ & $\mathrm{HCD}$ \\
\hline Growing & EMP & & PJ & \\
\hline Late Season & WMP & & & \\
\hline $\begin{array}{l}\text { Temperature- } \\
\text { Min }\end{array}$ & EMP (Apr) & & $\begin{array}{l}\text { HCD } \\
\text { (Nov) }\end{array}$ & \\
\hline $\begin{array}{l}\text { Temperature- } \\
\text { Max }\end{array}$ & & & $\begin{array}{l}\text { HCD } \\
\text { (Mar) }\end{array}$ & $\begin{array}{l}\mathrm{HCD} \\
(\mathrm{Jan}) \\
\end{array}$ \\
\hline \multicolumn{5}{|c|}{ Infrastructure and Price variables } \\
\hline Irrigation & \multicolumn{2}{|c|}{ Canal, Well } & \multicolumn{2}{|c|}{ Canal, Well } \\
\hline $\begin{array}{l}\text { Price of } \\
\text { Wheat }\end{array}$ & \multicolumn{2}{|c|}{ MSP, Market } & \multicolumn{2}{|c|}{ MSP, Market } \\
\hline Deflator & \multicolumn{2}{|c|}{ Fertilizer } & \multicolumn{2}{|c|}{ Fertilizer } \\
\hline
\end{tabular}

\begin{tabular}{|l|l|}
\hline \multicolumn{2}{|l|}{ Table A4: Abbreviation of Meteorological Subdivision } \\
\hline ASM & Assam \& Meghalaya \\
\hline SWB & Sub-Himalayan W. Bengal \& Sikkim \\
\hline GWB & Gangetic West Bengal \\
\hline OR & Orissa \\
\hline JH & Jharkhand \\
\hline BH & Bihar \\
\hline EUP & East Uttar Pradesh \\
\hline WUP & West Uttar Pradesh \\
\hline UT & Uttarakhand \\
\hline HCD & Haryana Chandigarh And Delhi \\
\hline PJ & Punjab \\
\hline HP & Himachal Pradesh \\
\hline JK & Jammu \& Kashmir \\
\hline WRJ & West Rajasthan \\
\hline ERJ & East Rajasthan \\
\hline WMP & West Madhya Pradesh \\
\hline EMP & East Madhya Pradesh \\
\hline SK & Saurashtra And Kutch \\
\hline KG & Konkan \& Goa \\
\hline MMH & Madhya Maharashtra \\
\hline VDB & Vidarbha \\
\hline CH & Chhattisgarh \\
\hline CAP & Coastal Andhra Pradesh \\
\hline TL & Telangana \\
\hline RY & Rayalseema \\
\hline TN & Tamilnadu \& Pondicherry \\
\hline CKR & Coastal Karnataka \\
\hline NIKR & North Interior Karnataka \\
\hline SIKR & South Interior Karnataka \\
\hline Source: IMD, Website \\
\hline
\end{tabular}

